\title{
O katedře finančního účetnictví a auditingu Fakulty financí a účetnictví VŠE v Praze
}

Vážený čtenáři,

spolu s čtvrtým číslem Českého finančního a účetního časopisu se mi touto cestou dostalo možnosti představit katedru finančního účetnictví a auditingu Fakulty financí a účetnictví Vysoké školy ekonomické v Praze. Katedra finančního účetnictví a auditingu (KFÚA), je jednou ze tří, kateder, jejíž pracovníci tvoří řešitelský kolektiv dlouhodobého výzkumného záměru MŠMT Rozvoj účetní a finanční teorie a její aplikace v praxi z interdisciplinárního hlediska, jehož jedním z významných výstupů je založení a vydávání tohoto vědeckého časopisu zaměřeného na prezentaci výsledků vědecko-výzkumné činnosti zejména v oblasti financí, účetnictví a daní.

Katedra finančního účetnictví a auditingu navazuje na bohatou a dlouhou tradici katedry účetnictví, která pařila od založení Vysoké školy ekonomické k významným katedrám profilujícím svojí výukou nejen absolventy vlastního studijního oboru, ale i absolventy všech ostatních fakult VŠE v Praze prostřednictvím výuky různých kurzů účetnictví, které patřily vždy do společného vědomostního základu studia na VŠE v Praze. V roce 1990 se katedra účetnictví rozdělila na katedru finančního účetnictví a katedru manažerského účetnictví a v roce 2006 došlo o doplnění názvu katedry finančního účetnictví o auditing.

Katedra finančního účetnictví a auditingu zabezpečuje na všech fakultách VŠE v Praze výuku základního kurzu účetnictví, který byl počínaje rokem 2006 zásadně restrukturalizován, inovován a reakreditován pro potřeby výuky v rámci ECTS. Kromě celoškolsky povinných kurzů vyučuje katedra řadu specializovaných kurzi̊ pro studenty bakalářského a inženýrského studia specializace „Účetnictví a finanční řízení podniku“, které je garantem a na jejímž zabezpečování se podílí zejména se sesterskou katedrou manažerského účetnictví a katedrou financí a oceňování podniku. Dále nabízí katedra studentům celé VŠE v Praze řadu kurzů volitelných. Celkem se jedná o více než 35 různých kurzů zaměřených na nejrůznější aspekty finančního účetnictví a auditingu. Na katedře je možno po ukončení inženýrského stupně studia pokračovat $\mathrm{v}$ doktorském studiu se stejným názvem "Účetnictví a finanční řízení podniku". V oboru „Účetnictví a finanční řízení“ se na katedře habilitovala řada docentů a profesorů.

Katedra finančního účetnictví a auditingu patří počtem svých stálých pracovníků po celou dobu své existence $\mathrm{k}$ jedněm $\mathrm{z}$ největších kateder na VŠE v Praze, v současnosti na katedře pracuje $\mathrm{v}$ plném pracovním úvazku více než 30 pracovníků. V průběhu existence katedry na ní pracovala a pracuje řada významných odborníků v oblasti účetnictví a auditingu, kteří prezentují katedru svojí vědecko-výzkumnou činností, publikační činností, přednáškovou činností a činností v orgánech tuzemských i zahraničních profesních organizací a redakčních radách odborných časopisů. Členové katedry v minulosti i v současnosti zastávali nejrůznější akademické funkce nejen $\mathrm{v}$ rámci fakulty, ale i na úrovni VŠE v Praze jako celku. V této souvislosti považuji za vhodné uvést alespoň některé: prof. Pilný, děkan fakulty; doc. Nováková, proděkanka, děkanka fakulty a prorektorka VŠE v Praze; doc. Králíček, předseda akademického senátu VŠE v Praze (AS VŠE) a prezident Komory auditorů ČR (KAČR); prof. Janhuba, proděkan a předseda akademického senátu VŠE v Praze; doc. Míková proděkanka; prof. Müllerová, viceprezidentka KAČR a zástupce fakulty v Národní účetní radě 
(NÚR); doc. Žárová, poradkyně děkana a zástupce fakulty v NÚR, členka výkonného výboru Evropské účetní asociace (European Accounting Association - EAA); Ing. Mejzlík, tajemník AS VŠE v Praze zástupce fakulty v NÚR a národní koordinátor EAA pro ČR. Mezi osobnosti, které profilovaly pedagogickou a vědeckou činnost katedry a představují odborné autority přesahující rámec katedry a VŠE v Praze, patř́ také prof. Báča, prof. Kovanicová a prof. Vomáčková.

Pro odborníky z praxe organizuje katedra již od roku 2001 dva kurzy celoživotního vzdělávání: Mezinárodně uznávané účetní standardy a Finanční účetnictví pro pokročilé. Těmito kurzy prošlo za dobu jejich pořádání s pozitivním ohlasem více než 300 absolventů. Zároveň je katedra pořadatelem dalších odborných akcí, jako je například již několik let se opakující Pedagogická konference zaměřená na vytvoření a udržování vazeb mezi středoškolskou a vysokoškolskou výukou účetnictví a mezinárodní konference Účetnictví v procesu celosvětové harmonizace, která je pořádána ve spolupráci s partnerskou katedrou účtovníctva Ekonomickém univerzity v Bratislavě ap.

Pracovníci katedry účetnictví byli a jsou řešiteli řady vědecko-výzkumných projektů, grantů, výzkumných úkolů a rozvojových programů. Mezi ty, které nejvíce ovlivnily $\mathrm{v}$ minulosti odbornou úroveň katedry a projevily se podstatně také v pedagogické práci katedry patřily dva rozsáhlé trríleté granty Grantové agentury ČR: Analýza rozdílu účetní soustavy České republiky a mezinárodnich účetnich standardì, určení priorit jejich řě̌ení (GA402/97/0790, 1997 - 2000) a Americké účetní standardy US GAAP a jejich role v celosvětové harmonizaci účetnictví (GA402/01/0160, 2001-2003). Řešení těchto dvou zásadních vědeckých grantů vedlo nejen k úspěšnému obhájení výstupů těchto grantů, ale vytvořilo předpoklady i pro úspěšné zapojení katedry do celé řady dalších projektů, z nichž je nezbytné zmínit zejména podíl většiny pracovníkủ katedry na prvním oficiálním překladu Mezinárodních standardů účetního výkaznictví (IFRS) do češtiny v roce 2000 a dále pak i na jejich aktualizovaném vydání v roce 2003 a 2005. Zkušenosti získané z práce na těchto překladech umožnily zapojení pracovníků katedry rovněž do projektu Nejvyššího kontrolního úřadu na př́pravu a vydání prvního oficiálního překladu Mezinárodních účetních standardů pro veřejný sektor (IPSAS) do češtiny

Katedra finančního účetnictví byla a je tradičně známa svou intenzivní spoluprací s profesními organizacemi, s legislativními a regulačními orgány a s praxí obecně. Např́íklad prostřednictvím účasti VŠE v Praze v Národní účetní radě ovlivňují zástupci katedry př́pravu legislativy $\mathrm{v}$ oblasti účetnictví a auditingu. Pracovníci katedry pracují v samosprávných orgánech, odborných výborech a komisích Komory auditorů ČR a Svazu účetních a jsou zapojeni do jejich vzdělávacích systémů před vstupem do profese i do systémů kontinuálního profesního vzdělávání. Rovněž působí jako odborní garanti zkoušek a zkušební komisaři těchto organizací. K tradiční formě spolupráce s praxí patří kontakty s auditorskými firmami, které jsou častým partnerem při pořádání konferencí a obdobných akcí katedry a rovněž se podílí na výuce vysíláním svých významných odborníků na přednášky a semináře vyučované katedrou.

Od roku 2005 se KFÚA účastní rovněž projektu Corporate Chair, který je zaměřen na firemní podporu konkrétních vybraných mladých učitelů VŠE v Praze. Jeho podstatou je významná finanční podpora ze strany firem konkrétním učitelům na základě dlouhodobé smlouvy, v rámci které se učitel zavazuje pracovat na VŠE v Praze, připravit nový kurz nebo učební pomůcky pro něj a zvýšit si svoji kvalifikaci. V prŕípadě KFÚA se jedná o smlouvu s auditorskou firmou PricewaterhouseCoopers pro Ing. Jiř́ího Peláka, Ph.D. 
Kromě auditorských firem rozvíjí katedra finančního účetnictví a auditingu rovněž spolupráci s průmyslovými a obchodními podniky, mezi nimiž je možno jmenovat zejména společnost Siemens, Severočeské doly apod. Významná je rovněž expertní a poradenská činnost pracovníků katedry při zpracování znaleckých posudků pro soudy a podobné prŕípady.

Ve výčtu odborných činností katedry finančního účetnictví a auditingu nelze opomenout její zahraniční aktivity. Pracovníci katedry se již od roku 1989 účastní výročních kongresů Evropské účetní asociace (EAA), kde prezentovali výsledky své vědecko-výzkumné činnosti. Tyto mezinárodní kongresy patří k nejvýznamnějším odborným akcím akademického charakteru, a to nejen v Evropském měřitku. $\mathrm{Na}$ základě mezinárodních aktivit pracovníků katedry a jejich činnosti v EAA, byla VŠE v Praze pověřena organizací 27. výročního kongresu EAA, který se konal v prostorách VŠE v dubnu 2004. Kongresu se zúčastnil rekordní počet cca 1300 účastníků $\mathrm{z}$ celého světa a $\mathrm{v}$ jeho průběhu bylo předneseno více než 600 odborných prŕspěvků z oblasti účetnictví a finančního řízení podniků. Organizaci kongresu zabezpečovali zejména učitelé katedry finančního účetnictví a dále kateder manažerského účetnictví a katedry financí a oceňování podniku za přispění všech útvarů VŠE v Praze, studentů, sponzorů a jiných externích firemních partnerů.

Přestože nelze $v$ rámci prostoru vymezeném tímto př́spěvkem zhodnotit veškeré aktivity KFÚA v minulosti ani vyjmenovat její současné činnosti, doufám, že se mi zde podařilo podat základní informaci o postavení a významu katedry a jejích pracovníků v pedagogické a vědecko-výzkumné práci v oblasti finančního účetnictví a auditingu. Př́ípadné zájemce o další a podrobnější informace o činnosti katedry, zájemce o spolupráci s katedrou nebo o účast na akcích pořádaných katedrou, či zájemce o studium oborů garantovaných katedrou

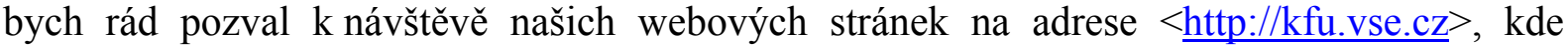
naleznou podrobnější a aktuální informace o práci katedry.

Ing. Ladislav Mejzlík, Ph.D.

vedoucí Katedry finančního účetnictví a auditingu

Fakulty financí a účetnictví

Vysoká škola ekonomická v Praze

a člen řešitelského týmu výzkumného záměru

Rozvoj účetní a finanční teorie

a její aplikace v praxi z interdisciplinárního hlediska 